\title{
Effect Of Planting Spacing In Production And Permeability Of Heartwood And Sapwood Of Eucalyptus Wood
}

\author{
Alice Soares Brito $^{1}$ (D), Graziela Baptista Vidaurre ${ }^{1}$ (D), José Tarcísio da Silva Oliveira ${ }^{1}$ (D), \\ João Gabriel Missia da Silva ${ }^{1}$ (D), Brunela Pollastrelli Rodrigues ${ }^{1}$ (D), \\ Angélica de Cássia Oliveira Carneiro ${ }^{2}$ \\ ${ }^{1}$ Programa de Pós-graduação em Ciências Florestais, Universidade Federal do Espírito Santo - UFES, \\ Jerônimo Monteiro/ES, Brasil \\ ${ }^{2}$ Programa de Pós-graduação em Ciência Florestal, Universidade Federal de Viçosa - UFV, Viçosa/MG, Brasil
}

\begin{abstract}
The objective of this work was to evaluate the influence of different useful areas provided by the planting spacings $(3 \times 1,3 \times 2,3 \times 3,3 \times 4 \mathrm{~m})$ on the production and permeability of heartwood and sapwood of Eucalyptus grandis and Eucalyptus grandis $\times$ Eucalyptus urophylla clones at 4 years old. Regardless of the clone, there was no effect of planting spacing on the heartwood/sapwood relation and wood permeability. All clones showed a heartwood decrease with increased height, regardless of planting spacing, and E. grandis (B) was the only one that had its heartwood percentage positively and significantly correlated with the dendrometric variables $(\mathrm{DBH}$ and commercial height). The use of the dymethil yellow compound was indispensable in defining the heartwood and sapwood regions in the samples from $50 \%$ of the stem height. The heartwood permeability was low in all evaluated clones, suggesting vessel obstruction by tyloses or other deposits, while sapwood permeability reached $405.4 \mathrm{~cm}^{3} / \mathrm{cm}$.atm.s.
\end{abstract}

Keywords: heartwood formation, young trees, useful area.

\section{Efeito do Espaçamento de Plantio na Produção e Permeabilidade do Cerne e Alburno na Madeira de Eucalipto}

\begin{abstract}
RESUMO
O objetivo deste trabalho foi avaliar a influência de diferentes áreas úteis proporcionadas pelos espaçamentos de plantio $(3 \times 1,3 \times 2,3 \times 3,3 \times 4 \mathrm{~m})$ na produção e na permeabilidade do cerne e do alburno da madeira de clones de Eucalyptus grandis e Eucalyptus grandis $\times$ Eucalyptus urophylla, aos 4 anos de idade. Independente do clone, não houve efeito do espaçamento de plantio na relação cerne/alburno e na permeabilidade da madeira. Todos os clones apresentaram um decréscimo na quantidade de cerne com o aumento da altura do fuste, independentemente do espaçamento de plantio, e o E. grandis (B) foi o único que a percentagem de cerne correlacionou-se positiva e significativamente com as variáveis dendrométricas (DAP e altura comercial). O uso do composto dymethil yellow foi indispensável na demarcação das regiões do cerne e do alburno nas amostras a partir de $50 \%$ da altura do fuste. A permeabilidade do cerne foi baixa em todos os clones avaliados, sugerindo obstrução dos vasos por tilas ou outras substâncias, enquanto a permeabilidade do alburno atingiu $405,4 \mathrm{~cm}^{3} / \mathrm{cm}$.atm.s.
\end{abstract}

Palavras-chave: formação do cerne, árvores jovens, área útil. 


\section{INTRODUCTION}

The proportion of heartwood and sapwood in the wood reflects directly in its use (Déjardin et al., 2010), since generally those that contain a high amount of heartwood (higher $\mathrm{H} / \mathrm{S}$ relation) are preferentially used in the construction and furniture industry, while trees with a greater proportion of sapwood (smaller H/S relation) are indicated for the pulp wood industry and for wood preservation, as they have higher proportions of high-permeability wood. In energy generation, smaller $\mathrm{H} / \mathrm{S}$ relation links would be most appropriate in the initial stage of carbonization, characterized by a wood drying stage (Pereira et al., 2013), while a higher $\mathrm{H} / \mathrm{S}$ relation would favor calorific value of the material.

The amount of heartwood and sapwood in the wood is a parameter of wood quality, and the percentage of each one varies significantly from species to species (Saito et al., 2008). In addition to the species, age, tree position, growth rate and silvicultural treatments also impact the amount of heartwood (Kumar \& Dhillon, 2014). The spacing between the trees influences the dendrometric variables such as height and stem diameter, and consequently heartwood formation (Gominho \& Pereira, 2005).

The proportion of heartwood and sapwood in young eucalyptus trees is still poorly addressed in wood quality evaluations, although it has an impact on several productive processes that use wood as raw material. In this context, the objective of this study was to evaluate the influence of different planting spacings on the production and permeability of the heartwood and sapwood in eucalyptus wood, to quantify the percentage of heartwood in the base-top direction of the stem, and to correlate its production with the trees dendrometric variables.

\section{MATERIAL AND METHODS}

Disks were taken from two Eucalyptus grandis tree clones and one Eucalyptus grandis $\times$ E. urophylla clonal hybrid from experimental planting of the Suzano Papel e
Celulose company, located in Paranapanema, São Paulo state, between the coordinates $23^{\circ} 23^{\prime} 19^{\prime \prime}$ latitude South and $48^{\circ} 43^{\prime} 22^{\prime \prime}$ longitude west, at an altitude of 610 meters. The region's soil is red latosol, the average temperature in the time period of the plantation (2010-2014) was approximately $20^{\circ} \mathrm{C}$, and the average annual precipitation was equal to $1300 \mathrm{~mm}$.

The experiment was initiated in August 2010, and the trees were collected at 4 years old, with the average diameter of the trees in each plot as a cut-off parameter. Twelve trees were removed per clone, three trees per spacing, totaling 36 trees. After cutting the selected trees, disks in diameter at breast height (DBH) and in the positions of 0 (base), $25 \%, 50 \%, 75 \%$ and $100 \%$ of the trees commercial height were removed for evaluating the production and permeability of the heartwood and sapwood. All discs were first manually polished in order to facilitate visualization and distinction of the two fractions.

Diameter at breast height $(1.30 \mathrm{~m})$ from ground level and total height of each sampled tree were measured (Table 1).

The heartwood/sapwood relation (H/S) was determined by dividing the mean heartwood diameter by the mean sapwood diameter, measured using a ruler graduated in millimeters. In addition to the visual evaluation on air dry discs, after properly sanded, one side of each disc was brushed along the shaft with $1 \mathrm{~g}$ of Dimethyl yellow solution dissolved in $500 \mathrm{ml}$ of ethanol in order to certify the exact boundaries between regions. Chemical compounds are considered as an acidity indicator, and finding the $\mathrm{pH}$ difference between the heartwood and sapwood regions allows delimiting the functional and non-functional xylem. The red-pinkish hue marks the heartwood region and indicates low $\mathrm{pH}$, whereas the yellow hue presented by the sapwood indicates a higher $\mathrm{pH}$ (Castro, 2014).

The total volume of the tree and the heartwood volume were obtained by the Smalian method, and the sapwood volume was calculated by the difference.

Table 1. Diameter at breast height $(\mathrm{DBH})$ and commercial average height of the trees for three clones of Eucalyptus.

\begin{tabular}{cccc} 
Dendrometric variables & \multicolumn{3}{c}{ Clone } \\
\cline { 2 - 4 } & E. grandis $(\mathbf{A})$ & E. grandis $(B)$ & E. grandis $\times$ E. urophylla \\
DBH $(\mathrm{cm})$ & 14.95 & 16.85 & 16.19 \\
Commercial height $(\mathrm{m})$ & 18.22 & 19.95 & 17.07 \\
\hline
\end{tabular}


The heartwood and sapwood percentage in the tree was calculated based on the volume.

Two heartwood samples and two sapwood samples (cylinders with an approximate diameter of $17 \mathrm{~mm}$ and an average length of $35 \mathrm{~mm}$ ) were removed from the base discs and used for the permeability analysis of the wood to air passage, totaling 144 test specimens (Figure 1). The regions of reaction wood and presence of knots were excluded in selecting samples. Each cylinder had its side surface sealed with paraffin to ensure flow only in the longitudinal direction of the sample.

The air flow in the sample used in the wood permeability analysis was determined by the flowmeter method as described by Siau (1971), adapted by Teixeira (2015). The equipment consists of four flowmeters connected in series using the following scales and sequence: 0.04 to 0.5 LPM (liters per minute), 0.2 to 2.5 LPM, 0.4 to $5.0 \mathrm{LPM}$, and 2.0 to $25.0 \mathrm{LPM}$, connected by PVC hoses to a vacuum pump. A vacuum of -3 pol.Hg was applied and the flow read output was obtained.

In order to determine the gaseous permeability of the wood, it was used the Equation 1 following Darcy's law:

$K g=\frac{\text { Q.L.Pi }}{\text { A. } \Delta \text { P.Pm }}$

In which $\mathrm{Kg}$ : permeability to gas $\left(\mathrm{cm}^{3} / \mathrm{cm}\right.$.atm.s); Q: gas flow volume through the specimen $\left(\mathrm{cm}^{3} / \mathrm{s}\right)$; L: sample length $(\mathrm{cm})$; Pi: input pressure, the ambient pressure (atm); A: cross-sectional area $\left(\mathrm{cm}^{2}\right) ; \Delta \mathrm{P}$ : pressure difference (atm); Pm: mean pressure on the specimen (atm).
The experiment was conducted in a completely randomized design (DIC). The data were evaluated for the assumptions of common variance (homoscedasticity) and normality of the experimental errors by Cochran and Shapiro-Wilk tests, respectively, both using $\alpha=0.01$. Next, linear regression analysis was performed with the purpose of analyzing the effect of the useful area (independent variable) of four spacings $(3 \times 1,3 \times 2,3 \times 3$, and $3 \times 4 \mathrm{~m})$ in the $\mathrm{H} / \mathrm{S}$ relation; the percentage of heartwood and sapwood; and heartwood and sapwood permeability. The relationship between the percentage of heartwood and the dendrometric variables (DBH and commercial height) was also evaluated using the Pearson linear correlation coefficient and its $\mathrm{P}$ value.

\section{RESULTS AND DISCUSSION}

\subsection{Heartwood and sapwood of eucalyptus} wood

The planting spacing did not influence the heartwood/sapwood relation, nor the percentage of heartwood and sapwood in any of the three evaluated clones.

In general, there was a tendency for the H/S relation (Figure 2), and consequently the percentage of heartwood (Figure 2), to increase as the useful area of the clone trees was increased for E. Grandis (B) and for E. grandis $\times$ E. urophylla hybrid. Increases of $34.3 \%$ and $32.9 \%$ of the $\mathrm{H} / \mathrm{S}$ relation were observed for these clones, respectively, of the smaller $(3 \times 1 \mathrm{~m})$ to the larger plant spacing $(3 \times 4 \mathrm{~m})$.
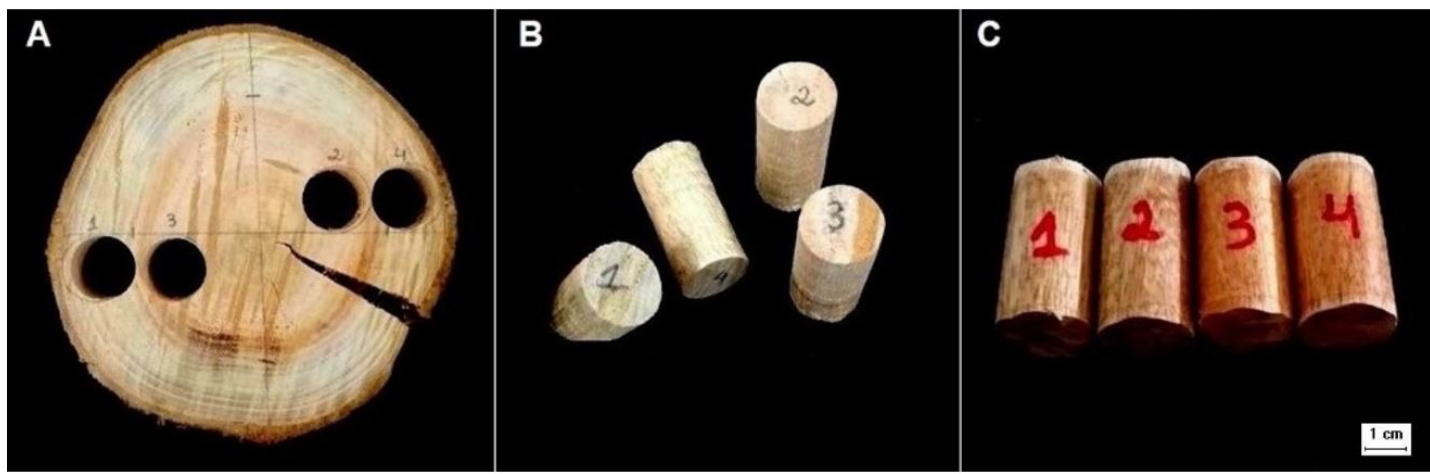

Figure 1. Illustration of sample removal for permeability in the disc (A); samples (B); and samples sealed with paraffin (C). 


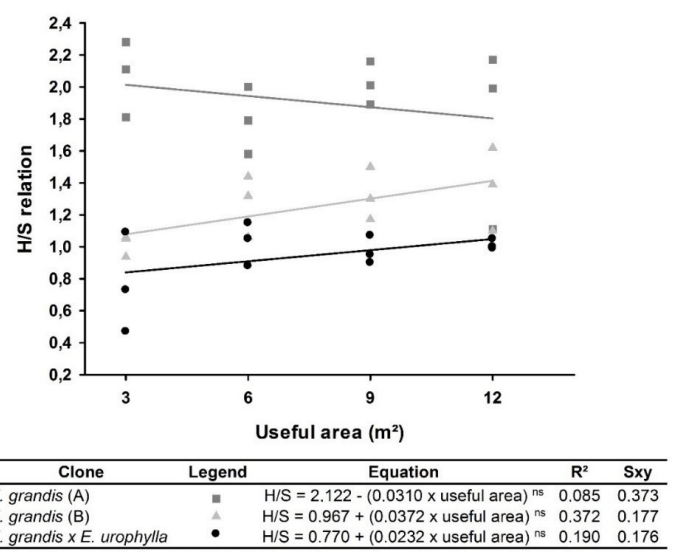

Figure 2. Linear regression to estimate the heartwood/ sapwood relation as a function of the useful area per tree $\left(\mathrm{m}^{2}\right)$ for the three Eucalyptus clones. ${ }^{\mathrm{n}}$ not significant; significant at $1 \%$ by the test $\mathrm{F}$ for regretion and $\mathrm{t}$ for coefficient of the equation.

The higher H/S relation indicates that the wood is composed of a large amount of heartwood. Wood with a high $\mathrm{H} / \mathrm{S}$ relation become less appropriate in drying, preservation, pulp production and carbonization processes. The predominant amount of heartwood impedes the passage of water from the interior to the surface of the piece, affecting the drying of the wood (Siau, 1971); this restricts the impregnation of preservatives, resulting in low retention of these products (Valle et al., 2013), increases the consumption of alkali and reduces the yield in cellulose, since the amount of extractives is high (Miranda et al., 2009); and finally, it prevents the gases from permeating the wood, causing cells breakage and fissures in charcoal (Pereira et al., 2013).

In general, $\mathrm{H} / \mathrm{S}$ relation values for eucalyptus wood ranged from 0.94 to 1.91 , being higher than those found by Cherelli (2015) for 4-year-old E. grandis and E. grandis $\times$ E. urophylla trees (0.84-1.61), and lower than those presented by Teixeira (2015) for 9-year-old E. grandis and E. grandis $\times$ E. urophylla (1.27-2.12). This variability between species, provenances and clones is natural (Panshin \& Zeeuw, 1980).

An increase in the $\mathrm{H} / \mathrm{S}$ relation in the $3 \times 1 \mathrm{~m}$ to $3 \times 4 \mathrm{~m}$ spacing was observed for three of the four 4-year-old E. grandis $\times$ E. urophylla clones (Feuchard, 2015). One of the genetic materials, as well as the E. grandis (A) clone (Figure 2), showed a tendency to reduce the H/S relation when planting spacing increased.

An increase in the amount of sapwood was verified in 18-year-old E. globulus trees grew at the widest spacing. This high percentage of sapwood is attributed to the greater development of the canopy provided by the greater useful area of the trees (Miranda et al., 2009). Shinozaki et al. (1964) described a functional relationship between the crown area and the sapwood area, known as the "Pipe Model", in other words, a unit of leaf area requires a corresponding unit of sapwood for support, which may justify the results found.

The amount of sapwood in the wood of $E$. grandis (B) and E. grandis $\times E$. urophylla clones decreased approximately $11 \%$ from the $3 \times 1 \mathrm{~m}$ to $3 \times 4 \mathrm{~m}$ spacing (Figure 3). Harris (2007) also observed an increase in basal area of sapwood in 4-year-old E. grandis wood with planting densification, confirming the trend found in this study.

Heartwood percentage values tended to increase at higher spacings for E. grandis (B) clones and E. grandis $\times$ E. urophylla hybrid (Figure 3) due to the higher height and diameter of these trees. The E. grandis (A) clone wood had a higher amount of heartwood than the other two clones, regardless of planting spacing. This is a justifiable fact since the heartwood formation may be under strong genetic control.

At 4 years old, the percentage of heartwood present in trees of $E$. grandis $(\mathrm{B})$ clones and the $E$. grandis $\times$ E. urophylla hybrid increased $44.7 \%$ and $58.3 \%$ from the $3 \times 1 \mathrm{~m}$ spacing to the $3 \times 4 \mathrm{~m}$, respectively. For 9-year-old variations of $E$. globulus values to the order of $45 \%$ to $61 \%$ of the $2 \times 1 \mathrm{~m}$ to $3 \times 3 \mathrm{~m}$ spacing (Gominho \& Pereira, 2005), and also values of $58 \%$ to $62 \%$ of the spacing $3 \times 2 \mathrm{~m}$ to $4 \times 5 \mathrm{~m}$ in E. globulus at a later age (18 years old), were observed (Miranda et al., 2009). The smallest heartwood content found in this study compared with the cited literature can be explained by the difference of age between the trees, as well as the difference of genetic material and site.

However, it is important to note that this is a natural tree development process, but this process is still not well-known in eucalyptus trees (Gominho et al., 2004), with the age that heartwood formation begins being imprecise. Kumar \& Dhillon (2014) suggest that heartwood formation originates around 3 to 5 years of growth. 
Young eucalyptus trees planted in Brazil were studied by Cherelli (2015) and Castro (2014), who confirmed heartwood formation at 2 and 3 years old, as observed for the three eucalyptus clones at 4 years old up to $50 \%$ of the trunk.
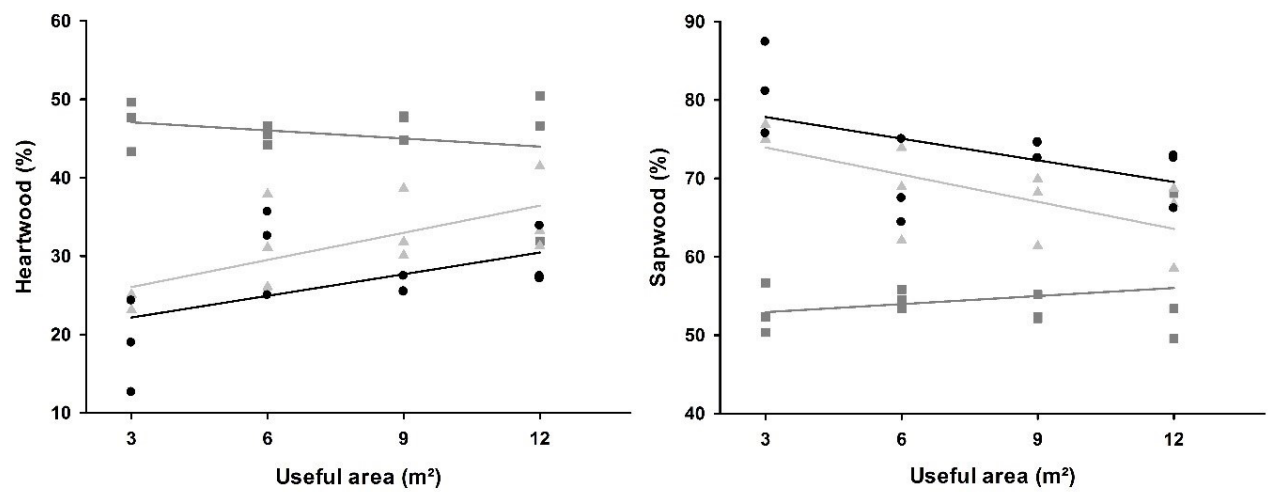

\begin{tabular}{|c|c|c|c|c|c|c|c|}
\hline Clone & Legend & Equation & $\mathrm{R}^{2}$ & Sxy & Equation & $\mathbf{R}^{2}$ & Sxy \\
\hline E. grandis (A) & - & $\% \mathrm{C}=49.296-(0.583 \times \text { useful area })^{\mathrm{ns}}$ & 0.093 & 6.696 & $\% A=50.704+(0.583 \times \text { useful area })^{n s}$ & 0.093 & 6.696 \\
\hline E. grandis (B) & $\triangle$ & $\% C=22.589+(1.154 \times \text { useful area })^{n s}$ & 0.475 & 4.454 & $\% \mathrm{~A}=77.411-(1.154 \times \text { useful area })^{\mathrm{ns}}$ & 0.475 & 4.454 \\
\hline E. grandis $x E$ urophylla & - & $\% \mathrm{C}=19.402+(0.921 \times \text { useful area })^{\mathrm{ns}}$ & 0.263 & 5.661 & $\% \mathrm{~A}=80.598-(0.921 \times \text { useful area })^{\mathrm{ns}}$ & 0.263 & 5.661 \\
\hline
\end{tabular}

Figure 3. Linear regression to estimate the percentage of heartwood and sapwood as a function of the useful area per tree $\left(\mathrm{m}^{2}\right)$ for three Eucalyptus clones. ${ }^{\text {ns }}$ not significant; significant at $1 \%$ by the test $\mathrm{F}$ for regretion and $\mathrm{t}$ for coefficient of the equation.
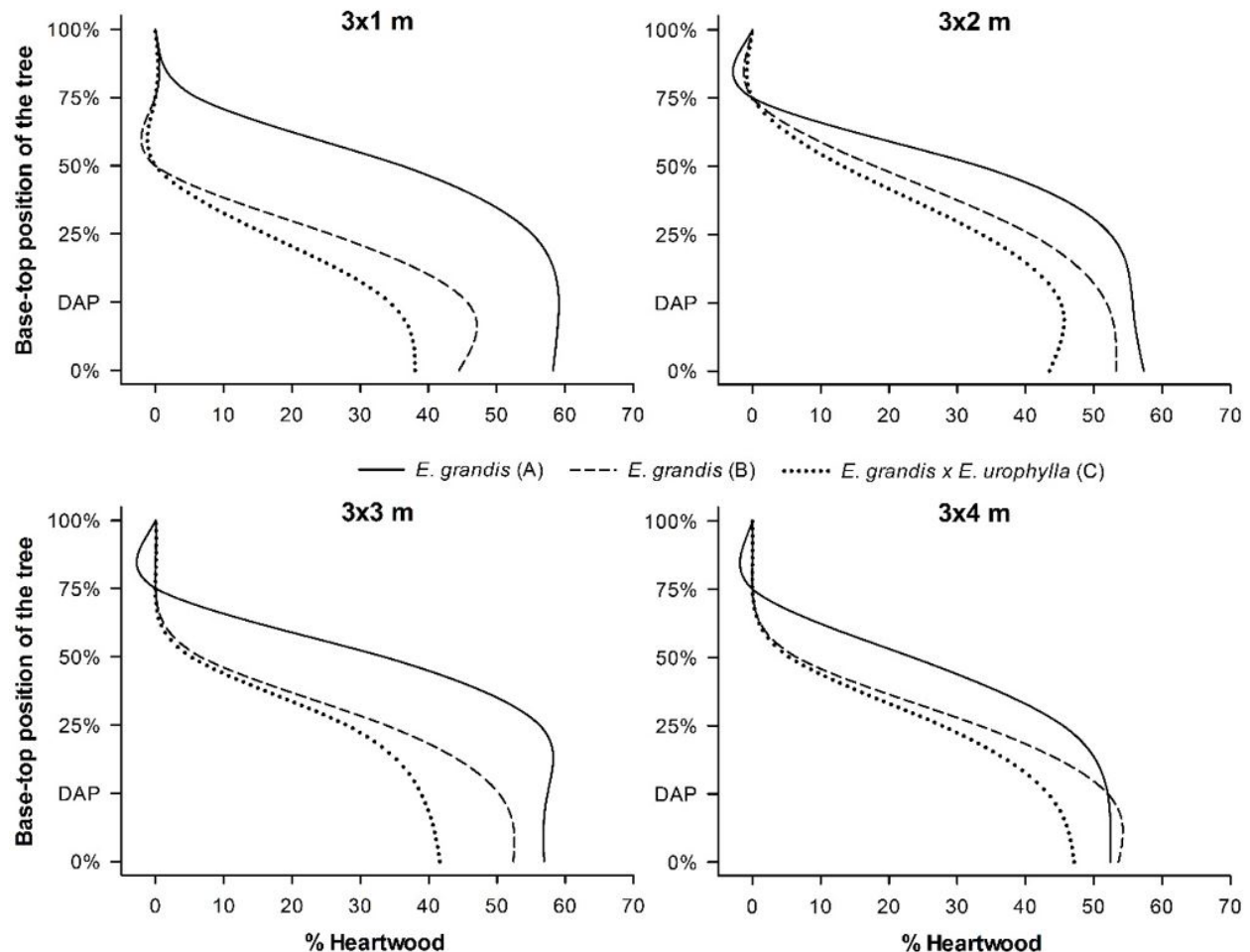

Figure 4. Percentage of heartwood in the base-top direction of the trees at different planting spacings in Eucalyptus clones. 
of the stem, as there are only layers of newly-formed wood in this region.

Reduction in heartwood percentages in the base-top direction of the stem was also observed in 7.5-year-old E. camaldulensis (Pereira et al., 2013; Costa et al., 2017); in 9-year-old Eucalyptus sp. (Teixeira, 2015); in 9-year-old E. globulus (Gominho \& Pereira, 2000; Gominho \& Pereira, 2005), 18-year-old (Miranda et al., 2015); and in E. grandis $\times E$. urophylla hybrids of approximately 5.6-year-old (Gominho et al., 2001) 6 and 14-year-old (Gonçalves et al., 2010). Heartwood development is proportional to the age of the wood, with this behavior justified by the higher proportion of juvenile wood in the upper tree positions (Pereira et al., 2013).

The height and the diameter of the tree also perform a fundamental role in heartwood formation (Beauchamp et al., 2012; DeBell \& Lachenbruch, 2009; Gominho \& Pereira, 2005). Table 2 shows the positive and significant correlations between heartwood percentage and $\mathrm{DBH}$; and between the percentage of heartwood and the commercial tree height for E. grandis clones (B) (Table 2).

The significance of the correlations for only the E. grandis (B) clone is related to its greater growth in relation to the other two evaluated clones, evidenced by the higher $\mathrm{DBH}$ and higher commercial height.

Positive and significant correlations between $\mathrm{DBH}$ and heartwood percentage were also found by Miranda et al. (2009) in 18-year-old E. globulus $\left(r^{2}=0.77\right)$, confirming that heartwood formation depends on secondary tree growth. Gominho \& Pereira (2005) found a high correlation $\left(r^{2}=0.82\right)$ between the height reached by the heartwood and the tree height, as well as between the heartwood percentage and the tree diameter $\left(r^{2}=0.95\right)$ in E. globulus at 9 years old, regardless of spacing, thus concluding that it is the tree dimensions that determine the heartwood proportion within the stem. Therefore, the growth in height and diameter positively influences the heartwood formation, which was also confirmed in this work.

In addition to the heartwood and sapwood demarcation through the wood's natural coloring, Dymethil yellow chemical compound was used for certifying and distinguishing the two regions, as the trees studied were young (4 years old) and the heartwood would probably still be in formation (Figure 5).

It was possible to distinguish between the heartwood and sapwood fractions by the natural coloration of the wood only at the base positions, $\mathrm{DBH}$ and at $25 \%$ of the commercial height. From 50\% stem height, it was indispensable using Dymethil yellow for heartwood demarcation.

It is shown that a pink coloration is accented in the pith regions and in the knots after application of the compound, regardless of the location of the disk (Figure 6).

\subsection{Eucalyptus wood heartwood and sapwood permeability}

The planting spacing did not influence the heartwood or even the sapwood permeability, independent of the clone, and despite the difference in flow between the

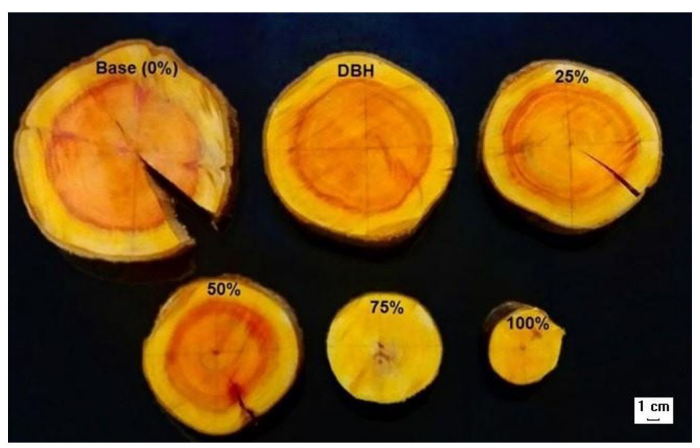

Figure 5. Cross section of the wood with heartwood and sapwood regions demarcated by Dymethil yellow at the six stem positions in Eucalyptus clones.

Table 2. Pearson correlation coefficients of heartwood percentage as a function of mean diameter at breast height $(\mathrm{DBH})$ and commercial tree height for the three Eucalyptus clones at 4 years old.

\begin{tabular}{cccc}
\multirow{2}{*}{ Variables } & \multicolumn{3}{c}{ Clone } \\
\cline { 2 - 4 } & $\boldsymbol{E}$. grandis $(\mathbf{A})$ & $\boldsymbol{E}$. grandis $(\mathbf{B})$ & $\boldsymbol{E}$. grandis $\times$ E. urophylla \\
DBH $(\mathrm{cm})$ & $-0.309^{\mathrm{ns}}$ & $\mathbf{0 . 7 1 8}^{*}$ & $0.466^{\mathrm{ns}}$ \\
Commercial height $(\mathrm{m})$ & $-0.102^{\mathrm{ns}}$ & $\mathbf{0 . 7 8 0}^{*}$ & $0.464^{\mathrm{ns}}$ \\
\hline
\end{tabular}

${ }^{\text {ns }}$ not significant. ${ }^{*}$ significant at $1 \%(\mathrm{P}<0.01)$. 
regions, with the heartwood permeability being up to 400 times smaller than that of the sapwood (Figure 7).

The permeability of the E. grandis $\times$ E. urophylla sapwood was higher in relation to the other clones, regardless of the adopted planting spacing. This difference in permeability between the genetic materials is due to the great complexity and heterogeneity of the wood, mainly by the distribution and number of conductive elements (Siau, 1984) and chemical composition of the material.

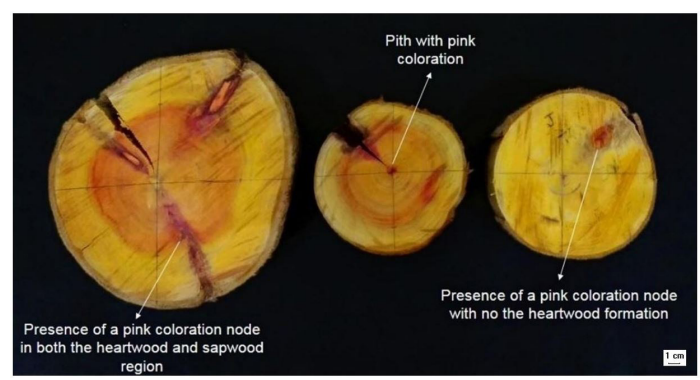

Figure 6. Cross section of the wood with demonstration of the pith and knots after Dymethil yellow application in Eucalyptus clones at 4 years old.
The average values of sapwood permeability observed in this work were lower than those found by Oliveira (2015), and higher than those found by Pinheiro (2013), both for 5-year-old E. urophylla (469.5 and $216.9 \mathrm{~cm}^{3} / \mathrm{cm}$.atm.s., respectively).

According to Siau (1984) and Baraúna et al. (2014), the heartwood and sapwood proportion affects the wood permeability, which is evidenced by the three clones when presenting permeability values and $\mathrm{H} / \mathrm{S}$ relation in inverse proportions (Table 3).

Heartwood permeability ranged from 0 to $3.9 \mathrm{~cm}^{3} / \mathrm{cm}$.atm.s. (Figure 7 ), showing that it is practically impermeable even in young wood, which may be explained by complete or partial pore obstruction by tyloses, gum and/or other substances (Silva et al., 2010; Micco et al., 2016; Taghiyari et al. 2010). Low heartwood permeability was also observed in E. urophylla wood at 5 years old (Oliveira, 2015); E. grandis and E. grandis $\times$ E. urophylla at 9 years old (Teixeira, 2015); and E. citriodora and E. grandis at 25 and 100 years old, respectively (Silva et al., 2010).

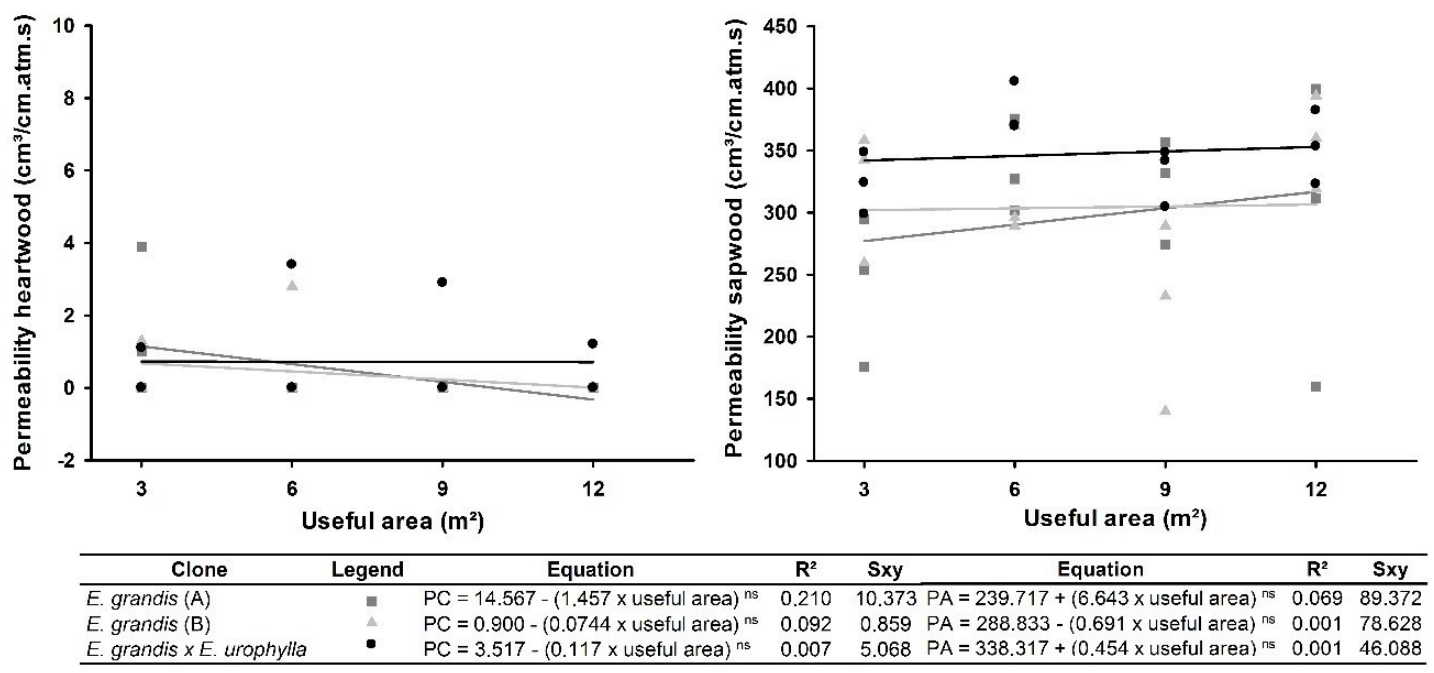

Figure 7. Linear regression to estimate the heartwood and sapwood permeability as a function of the useful area per tree $\left(\mathrm{m}^{2}\right)$ for the three Eucalyptus clones. ${ }^{\mathrm{ns}}$ not significant; ${ }^{* *}$ significant at $1 \%$ by the test $\mathrm{F}$ for regretion and $\mathrm{t}$ for coefficient of the equation.

Table 3. Average permeability values ( $\mathrm{cm}^{3} / \mathrm{cm}$.atm.s.) of the sapwood and $\mathrm{H} / \mathrm{S}$ relation of the three Eucalyptus clones.

\begin{tabular}{cccc}
\multirow{2}{*}{ Variables } & \multicolumn{3}{c}{ Clone } \\
\cline { 2 - 4 } & $\boldsymbol{E}$. grandis $(\mathbf{A})$ & $\boldsymbol{E}$. grandis $(\mathrm{B})$ & $\boldsymbol{E}$. grandis $\times$ E. urophylla \\
Sapwood permeability & 296.9 & 304.2 & 347.5 \\
H/S relation & 1.91 & 1.25 & 0.94 \\
\hline
\end{tabular}


Independent of the age of cut, heartwood presents low permeability for eucalyptus wood.

It is important to remember that although permeability and porosity are interconnected, the pores must be unobstructed and interconnected in order for the wood to be permeable (Siau, 1984). According to Taylor et al. (2002), sapwood permeability is facilitated precisely by the presence of non-embedded functional pits and low extractive content, unlike heartwood.

\section{CONCLUSIONS}

The useful area provided by planting spacing did not affect permeability, percentage or heartwood/sapwood relation, independent of the clone evaluated.

All clones showed a decrease of the heartwood content with stem height, regardless of the planting spacing.

E. grandis (B) wood was the only one that had its heartwood percentage positively and significantly correlated with the dendrometric variables (DBH and commercial height).

The use of Dymethil yellow compound was indispensable in demarcating the heartwood and sapwood fractions in the samples from $50 \%$ commercial height.

Heartwood permeability was low in all evaluated clones, suggesting vessel obstruction by tyloses or other substances, while sapwood permeability reached $405.4 \mathrm{~cm}^{3} / \mathrm{cm}$.atm.s.

\section{ACKNOWLEDGEMENTS}

Suzano Papel e Celulose, to forestry engineers Leandro de Siqueira and Marina Valin, and the Coordenação de Aperfeiçoamento de Pessoal de Nível Superior - CAPES.

\section{SUBMISSION STATUS}

Received: 12 oct., 2018

Accepted: 4 dec., 2018

\section{CORRESPONDENCE TO}

\section{Alice Soares Brito}

Programa de Pós-graduação em Ciências Florestais, Departamento de Ciências Florestais e da Madeira, Universidade Federal do Espírito
Santo - UFES, Av. Gov. Lindemberg, 316, Centro, CEP 29550-000, Jerônimo Monteiro, ES, Brasil e-mail: soaresbritoalice@gmail.com

\section{REFERENCES}

Baraúna EEP, Lima JT, Vieira RS, Silva JRM, Monteiro TC. Effect of anatomical and chemical structure in the permeability of "Amapá" wood. Cerne 2014; 20(4): 529534. http://dx.doi.org/10.1590/01047760201420041501.

Beauchamp K, Mencuccini M, Perks M, Gardiner B. The regulation of sapwood area, water transport and heartwood formation in Sitka spruce. Plant Ecology \& Diversity 2012; 6(1): 45-56. http://dx.doi.org/10.1080/1 7550874.2012.702359.

Castro VR. Efeito do potássio, sódio e da disponibilidade hídrica no crescimento e qualidade do lenho de árvores de Eucalyptus grandis Hill ex Maiden [tese]. Piracicaba: Universidade de São Paulo, Escola Superior de Agricultura "Luiz Queiroz"; 2014.

Cherelli SG. Cerne e alburno em eucaliptos: influência da espécie e da idade nas propriedades tecnológicas [dissertação]. Botucatu: Universidade Estadual Paulista, Faculdade de Ciências Agronômicas; 2015.

Costa ACS, Leal CS, Santos LC, Carvalho AMML, Oliveira AC, Pereira BLC. Propriedades da madeira de cerne e alburno de Eucalyptus camaldulensis. Brazilian Journal of Wood Science 2017; 8(1): 10-20.

DeBell JD, Lachenbruch B. Heartwood/sapwood variation of western redcedar as influenced by cultural treatments and position in tree. Forest Ecology and Management 2009; 258(9): 2026-2032. http://dx.doi.org/10.1016/j. foreco.2009.07.054

Déjardin A, Laurans F, Arnaud D, Breton C, Pilate G, Leple JC. Wood formation in Angiosperms. Comptes Rendus Biologies 2010; 333(4): 325-334. http://dx.doi. org/10.1016/j.crvi.2010.01.010. PMid:20371107.

Feuchard LD. Influência do espaçamento de plantio e idade de colheita na qualidade da madeira de eucalipto para celulose [dissertação]. Jerônimo Monteiro: Universidade Federal do Espírito Santo; 2015.

Gominho J, Figueira J, Rodrigues JC, Pereira H. Withintree variation of heartwood, extractives and wood density in the eucalypt hybrid urograndis (Eucalyptus grandis $\mathrm{x}$ E. urophylla). Wood and Fiber Science 2001; 33(1): 3-8.

Gominho J, Knapic S, Pereira H. Cerne e borne - factores de variação da qualidade tecnológica das árvores. Revista Sociedade Portuguesa dos Materiais 2004; 16: 99-107.

Gominho J, Pereira H. Variability of heartwood content in plantation-grown Eucalyptus globulus Labill. Wood and Fiber Science 2000; 32(2): 189-195. 
Gominho J, Pereira H. The influence of tree spacing in heartwood content in Eucalyptus globulus Labill. Wood and Fiber Science 2005; 37(4): 582-590.

Gonçalves FG, Oliveira JTS, Silva GF, Nappo ME, Tomazelo M Fo. Parâmetros dendrométricos e correlações com as propriedades tecnológicas em um híbrido clonal de Eucalyptus urophylla $\mathrm{x}$ Eucalyptus grandis. Revista Árvore 2010; 34(5): 947-959. http://dx.doi.org/10.1590/S010067622010000500020 .

Harris F. The effect of competition on stand, tree, and wood growth and structure in subtropical Eucalyptus grandis plantations [thesis]. Lismore: School of Environmental Science and Management, Southern Cross University; 2007.

Kumar A, Dhillon GPS. Variation of sapwood and heartwood content in half-sib progenies of Eucalyptus tereticornis Sm. Indian Journal of Natural Products and Resources 2014; 5(4): 338-344.

Micco V, Balzano A, Wheeler EA, Baas P. Tyloses and gums: a review of structure, function and occurrence of vessel occlusions. IAWA Journal 2016; 37(2): 186-205. http://dx.doi.org/10.1163/22941932-20160130.

Miranda I, Gominho J, Pereira H. Variation of heartwood and sapwood in 18-year-old Eucalyptus globulus trees grown with different spacings. Trees (Berlin) 2009; 23(2): 367-372. http://dx.doi.org/10.1007/s00468-008-0285-9.

Miranda I, Gominho J, Pereira H. Heartwood, sapwood and bark variation in coppiced Eucalyptus globulus trees in 2 nd rotation and comparison with the single-stem 1st rotation. Silva Fennica 2015; 49(1): 1-13. http://dx.doi. $\operatorname{org} / 10.14214 /$ sf.1141.

Oliveira AC. Secagem de toras de eucalipto [tese]. Viçosa: Universidade Federal de Viçosa; 2015.

Panshin AJ, De Zeeuw C. Textbook of wood technology. New York: Mc-Graw Hill; 1980.

Pereira BLC, Oliveira AC, Carvalho AMML, Carneiro ACO, Vital BV, Santos LC. Correlações entre a relação cerne/alburno da madeira de eucalipto, rendimento e propriedades do carvão vegetal. Scientia Forestalis 2013; 41(98): 217-225.

Pinheiro MA. Influência das dimensões da madeira na secagem e nas propriedades do carvão vegetal [dissertação]. Viçosa: Universidade Federal de Viçosa; 2013.

Saito K, Mitsutani T, Imai T, Matsushita Y, Yamamoto A, Fukushima K. Chemical differences between sapwood and heartwood of Chamaecyparis obtusa detected by ToF-SIMS. Applied Surface Science 2008; 255(4): 10881091. http://dx.doi.org/10.1016/j.apsusc.2008.05.145.

Shinozaki K, Yoda K, Hozumi K, Kira T. A quantitative analysis of plant form - the pipe model theory I. basic analyses. Japanese Journal of Ecology 1964; 14(3): 97-105.

Siau JF. Flow in wood. New York: Syracuse University Press; 1971.

Siau JF. Transport processes in wood. Berlin: SpringerVerlag; 1984. http://dx.doi.org/10.1007/978-3-642-69213-0.

Silva MR, Machado GO, Deiner J, Calil C Jr. Permeability mensuremens of brasilian Eucalyptus. Materials Research 2010; 13(3): 281-286. http://dx.doi.org/10.1590/S151614392010000300002 .

Taghiyari HR, Karimi AN, Parsapajouh D, Pourtahmasi K. Study on the longitudinal gas permeability of juvenile wood and mature wood. Special Topics \& Reviews in Porous Media — International Journal 2010; 1(1): 31-38.

Taylor AM, Gartner BL, Morrell JJ. Heartwood formation and natural durability - A review. Wood and Fiber Science 2002; 34(4): 587-611.

Teixeira RU. Efeito da produtividade florestal e permeabilidade da madeira de eucalipto na velocidade de secagem [dissertação]. Viçosa: Universidade Federal de Viçosa; 2015.

Valle MLA, Silva JDC, Lucia RMD, Evangelista WV. Retenção e penetração de CCA em madeira de primeira e segunda rotação de Eucalyptus urophylla S.T. Blake. Ciência Florestal 2013; 23(2): 481-490. http://dx.doi. org/10.5902/198050989292. 